THEORETICAL FOUNDATIONS OF THE FUNCTIONING OF EDUCATION. WAYS TO

IMPROVE THE EFFECTIVENESS OF EDUCATIONAL ACTIVITIES

SECTION 2. GENERAL AND PRE-SCHOOL PEDAGOGY

\title{
2.1 Жоғары мектеп оқытушысының тұлғалық даму ерекшеліктерін типологиялық жіктеу теориялары
}

Педагогикалық, психологиялық зерттеуде кәсіби маңызды тұлғалық қасиеттердің интеграцияланып, синтезделуінен жинақталатын және әрбір тұлғаның жеке даралығын сипаттайтын композицияны педагогтың «типологиялық» ерекшеліктері немесе «типтік» ерекшеліктері деп анықталады.

Типтік талдау, типология гректің «tipos» деген сөзінен шыққан. Бұл термин бір заттың немесе құбылыстың ерекшеліктеріне байланысты қалдырған ізі, бейнесі, формасы, үлгісі мағынасын білдіреді.

Ғылыми еңбектерде типология арқылы танымдық әдіс анықталып, ғылыми тұрғыдан типологиялық тұрғы екі түрлі үдерісті сипаттайды:

1) типология - жүйені құрамдарға ажыратып, талдау;

2) құрамдарды идеалды түрде белгілі бір модельге, типке сәйкес топтастырып, сипаттау.

Адамның тұлғалық құрылымын қарастыратын типологиялық тұрғының көптеген теориялары бар. Мысалы, адам дамуындағы ерекшеліктерді типтерге бөлуде гуморальдік (Гиппократ, П. Лесгафт), конституциялық немесе физикалық (Э. Кречмер, У. Шелдон), психофизиологиялық (И.П. Павлов, Б.М. Теплов, В.С. Мерлин, т.б.), психоанализдік (3. Фрейд, К. Юнг, т.б.), мінез бітісіне байланысты (Хейманс, Ле-Сенн, К. Леонгард, А.Е. Личко, т.б.), тұлғалық (К. Юнг, т.б.), психогеометриялық (С. Деллингер), т.с.с.

Психологиялық-педагогикалық ғылымдарда педагогтарды типтерге жіктеудің бірнеше түрлері мен олардың негіздемелері бар.

Бірақ, педагог тұлғасындағы типтік ерекшеліктерді анықтап, сипаттау оңай болмайды. Өйткені, педагог тұлғасы «адам-адам» саласындағы басқа да мамандар сияқты білім алушылардың, ата-аналардың, әкімшіліктің, ғылымның, қоғамның талаптарына сәйкес аса күрделі құрылымнан тұрады. Бұл туралы Ф.П. Гоноболин «Жақсы педагог туралы әрқашан ол әркезде қатал немесе жұмсақ, 
THEORETICAL FOUNDATIONS OF THE FUNCTIONING OF EDUCATION. WAYS TO IMPROVE THE EFFECTIVENESS OF EDUCATIONAL ACTIVITIES

белсенді немесе енжар, т.с.с. деп айту мүмкін емес. Ол жағдайға байланысты анандай да, мынандай да бола алады. Адамдармен қатынас жасауда жылылық керек. Бірақ аздап суық қатынас та қажет болады. Педагогтың көмегі оқушыларға дербестік берумен үйлесуі тиіс. Мұғалімнің алғашқы бастамашылығы біртіндеп оқушыларға өтуі керек» деп жазған [84, 109 б.].

Педагогикалық, психологиялық зерттеулердің көбінде педагогтардың кәсіби мінез-құлық ерекшеліктерін жеке-дара қабілеттер анықтайтыны негізге алынады. Мысалы, педагогтардың типтерін ажыратуда олардың кәсіби ісәрекеттегі қарым-қатынас жасауға қабілеті немесе өз пәні арқылы білім алушыларды қызықтыра алуы немесе педагогтардың психологиялық ерекшеліктерінің даму деңгейлері қарастырылады.

К. Левиннің іс-әрекеттегі жеке даралығы бойынша тұлғаны авторитарлық стиль, либералды стиль және демократиялық стиль бойынша жіктемесі нағыз классикалық типология болып табылады. Бұл стильдер бойынша типтер сипаттамасы педагогикалық-психологиялық зерттеулерде қолданылады. Осыған байланысты А.А. Бодалевтың, А.А. Леонтьевтің зерттеулерінде педагогтардың кәсіби-тұлғалық типтері авторитарлық стиль, либералды стиль және демократиялық стиль негізінде сипатталады. Мұнда педагогтардың типтік ерекшеліктері кәсіби іс-әрекет барысында қарым-қатынасты ұйымдастыру мен жүзеге асыруы арқылы анықталады.

В.А. Кан-Калик кәсіби педагогикалық қарым-қатынас стилін әлеуметтік және адамгершілік тұрғысынан қаралатын категория деп анықтап, педагогикалық қарым-қатынас стильдерін типтік ерекшеліктер ретінде анықтайды: «қарым-қатынас стилін педагог пен білім алушылардың әлеуметтікпсихологиялық өзара әрекеттесуінің жеке дара типологиялық ерекшеліктері деп түсінеміз» [85, 97 б.]. В.А. Кан-Каликтың 5 типтік жіктемесіне сәйкес педагогтың қарым-қатынас стилімен анықталатын жеке дара типологиялық ерекшеліктерді тұлғалық қасиеттерге байланысты қарастырылады: 
THEORETICAL FOUNDATIONS OF THE FUNCTIONING OF EDUCATION. WAYS TO

IMPROVE THE EFFECTIVENESS OF EDUCATIONAL ACTIVITIES

1. Бірлескен іс-әрекетке мүдделі болу негізіндегі қарым-қатынас. Қарымқатынастың бұл типі педагогтың жоғары кәсіби этикалық бағдарларына негізделеді; тұтастай кәсіби іс-әрекетке қатынасына негізделеді.

2. Достық негіздегі қарым-қатынас. Мұнда педагог тәлімгерлік, жолдастық қатынаспен бірге іскерлік бағыттылық бойынша ерекшеленеді.

3. Дистанция сақтау қарым-қатынасы. Бұл қарым-қатынас стилінде педагогтың мәртебелі болуды, кәсіпқой ретінде көрінуді, өмірлік тәжірибесі мен жас ерекшелігін алға қоюы бейнеленеді. Сонда бұл қарым-қатынас стилі педагогтың тұлғалық дамуындағы мәселені көрсетеді.

4. Үрейлендіру қарым-қатынасы. Бұл жас педагогтарға, бірлескен ісәрекетті шығармашылықпен ұйымдастыруға қабілеті жеткіліксіз педагогтар типіне сәйкес негативті қарым-қатынас стилі болып табылады.

5. Әзілдесу қарым-қатынасы. Бұл танымал болуға тырысатын жас педагогтардың жалған, арзан бедел жинауға, педагогикалық әдепті ұстанбауы арқылы сипатталатын типологиялық ерекшелік.

Әдебиетте бұдан басқа да педагог типтерінің жіктемесі бар. Солардың арасында М. Таленнің педагог типтерін 7 топқа жіктеуі кең таралған. Ол педагогтарды қызмет барысында тек өздерінің қажеттіліктеріне байланысты белгілі бір қарым-қатынас, іс-әрекет стилін таңдап алуы бойынша қарастырады. М. Таленнің жасаған жіктемесін А.Р. Ерментаеваның еңбегі [86, 138-140 бб.] бойынша көрсетеміз.

1) «Сократ». Бұл - сабақта әдейі пікірталасқа, пікірсайысқа қозғау салатын, оған әуестігімен ерекшеленетін педагог. Мұндай педагогтің оқу процесіне жекедаралық, жүйесіздік тән. Алайда, педагогтің бұл ұстанымы білім алушылардың өз көзқарастарын дәлелдеп, айта алуына жағдай жасайды; олардың ақыл-ой дербестіктерін күшейтеді.

2) «Топтық пікірсайыс жетекшісі». Бұл ұстанымда оку-тәрбие процесінде білім алушылармен келісе отырып, ынтымақтаса жұмыс істеуге аса мән беріледі. Мұнда педагог пікірсайыстан шығатын нақты нәтижені емес, білім алушылармен демократиялық түрде келісуді бәрінен артық қояды. 
THEORETICAL FOUNDATIONS OF THE FUNCTIONING OF EDUCATION. WAYS TO

IMPROVE THE EFFECTIVENESS OF EDUCATIONAL ACTIVITIES

3) «Шебер». Аталмыш ұстаным бойынша педагог үлгі ретінде болады. Сондықтан, оқу процесінде, жалпы, өмірдің барлық жағдайында оның айтқандары мен әрекеттерін білім алушылардың мүлтіксіз қайталау шарты қойылады.

4) «Генерал». Бұл ұстаным екі ұштылықтан аулақ, талапқойғыш, өзіне қатаң түрде бағындыратын педагогке тән. Ол өзінің айтқандары мен әрекеттерін әрқашан дұрыс санап, білім алушыға берген әмірін екі етпей орындауын міндеттейді.

5) «Менеджер». Аталмыш мәнер сыныптағы іс-әрекеттің табысты болуына, білім алушылардың бастамашылығын және дербестігін мадақтауға, қолдауға бағдарланады. Педагог әрбір білім алушының атқаратын міндетінің маңызын түсіндіріп, талдауға; әрқайсысының іс-әрекетін қалтқысыз бақылауға және қол жеткен нәтижелерін бағалауға тырысады.

6) «Жаттықтырушы». Бұл ұстаным бойынша сыныптағы қарым-қатынасқа корпорациялық рух тән. Мұнда білім алушылардың бір команданың ойыншылары сияқты жеке-дара жетістіктері емес, бірлескен іс-әрекеті маңызды болады. Ал, педагогке тек нәтиже, табыс, жеңіс ең басты мақсат болып табылады. Сондықтан ол топтық жұмысты жандандырушы, рухтандырушы рөлін атқарады.

7) «Гид». Білмейтіні жоқ, «энциклопедия» рөліндегі педагог қарымқатынастың осы мәнерімен сипатталады. Ол - әрқашан ұстамды, жинақы. Мұндай педагогтің қоятын сұрақтары да, кез келген сұраққа жауабы әзір тұрады. Оның іс-әрекетін мінсіз деуге тұрарлық.

M. Таленнің типологиясы педагогтардың кәсіби жұмысында өз қажеттіліктері, өз мүдделері негізге алынып жасалған.

Бірқатар зерттеушілер педагог типологиясын жасауда оның негізіне қарым-қатынас стилі мен нақты бір қабілеттің дамуын алады. Мысалы Б.П. Ковалев [87, 25б.] педагог типтерін екі белгі бойынша ажыратады:

- педагогтардың рефлексияға қабілеттілігі;

- педагогтардың қарым-қатынас стилі. 
THEORETICAL FOUNDATIONS OF THE FUNCTIONING OF EDUCATION. WAYS TO

IMPROVE THE EFFECTIVENESS OF EDUCATIONAL ACTIVITIES

Осыған байланысты зерттеуші педагогтарды 5 топқа бөліп, сипаттайды.

Бірінші топ педагогтарының өзін-өзі бағалауы білім алушылардың қатынасына сәйкес келеді. Бұл педагогтар қарым-қатынаста демократиялық стильмен ерекшеленеді.

Екінші топтағы педагогтар өздерін бағалауын дұрыс болжамдайды. Бірақ олардың өзін-өзі бағалауы адекватты бола қоймайды. Осыған байланысты бұл педагогтар қарым-қатынаста басыңқы, үстем қарым-қатынасты ұстанады.

Үшінші топтағы педагогтардың өзін-өзі бағалауы адекватты болады. Бірақ олар өздерін бағалауда дұрыс болжам жасамайды. Бұл педагогтар білім алушылармен қарым-қатынаста енжар болады және олармен мейірммен қатынас жасайды.

Төртінші топтағы педагогтардың өзі туралы түсініктері мен өзін-өзі бағалауы адекватты емес. Олар өзі туралы пікірді білім алушылардан білуге тырысады. Бірақ, бұл педагогтар қарым-қатынас жасауға икемді бола қоймайды. Бұл топтағы педагогтар қарым-қатынаста басым болады немесе олардың қарымқатынасына ситуациялық сипат тән.

Бесінші топтағы педагогтардың өздері туралы түсініктері білім алушылардың пікіріне қарама-қарсы келеді. Сондықтан бұл педагогтар қарымқатынаста әлдеқайда үлкен қиындықтарды кешеді.

Олай болса, бұл типологияда педагогтың да, білім алушылардың да педагог туралы ұстанымдары негізге алынған.

Ғылыми зерттеулерде педагог типтері кәсіби маңызды қасиеттер мен кәсіби бағыттылықтың дамуы бойынша да ажыратылады. Осыған байланысты Е.И. Рогов [88, 23 б.] педагогтардың негізгі 4 типін анықтаған, олар: «Ұйымдастырушы» педагог. Бұл педагог талап қою, ұйымдастыру, күшті ерікжігер, куаттылық сияқты қасиеттермен ерекшеленеді. Ұйымдастырушы педагогтар кәсіби іс-әрекетте орындаушы, жұмылдырушы қызметтерін жоғары деңгейде орындай алады.

1. «Сабақ өткізуші» педагог. Бұл педагогтарға байқампаздық, шығармашылық, кәсіби құзіреттілікке ұмтылу қасиеттері тән болады. Олар 
THEORETICAL FOUNDATIONS OF THE FUNCTIONING OF EDUCATION. WAYS TO IMPROVE THE EFFECTIVENESS OF EDUCATIONAL ACTIVITIES

рационалист ретінде білім алудың қажеттілігі мен білімнің өмірдегі маңызына ерекше назар аударады. «Сабақ өткізуші» педагог кәсіби іс-әрекетте конструктивті, әдіскерлік, білім беруші, бағдарлаушы қызметтерін тиімді жүзеге асырады.

2. «Коммуникатор» педагог. Оның ең басты қасиеттеріне қарымқатынастағы ашықтық, мейірімділік, тартымдылық, адамгершілік, эмоционалдық және жұғымды мінез-құлық жатады. «Коммуникатор» педагогтер эмпатиялық қабілетпен, білім алушыларды бөліп-жармай, оларға құнды қатынаспен ерекшеленеді.

3. «Зиялы» («ағартушы») педагог. Бұл педагогтар зиялылықтың, жалпы мәдениеттіліктің, ізгіліктіліктің жоғары деңгейімен ерекшеленеді. Олар талапшыл, мораль нормаларын қатаң ұстанатын тұлғалар. «Зиялы» педагог кәсіби іс-әрекетте гностикалық, тәрбиелеуші, ақпараттық, дамытушы, зерттеуші қызметтерін оңай үйлестіріп, атқарады. Сонымен қатар, бұл педагогтар өзін-өзі дамыту мәселесіне ерекше назар аударады.

Е.И. Рогов педагогтардың бұл басты типтерінің арасында қосалқы аралық типтер де болатынын ескертеді.

Қазіргі кезде педагогтың кәсіби құзіреттілігін анықтауда эмпатияны маңызды құрылым ретінде қарастыратын психологиялық-педагогикалық зерттеулер жеткілікті. Солардың арасында осы эмпатиялық қабілет арқылы Р. Атаханов пен М.Г. Бобкова [89, 316.] педагог типологиясын сипаттайды. Мұнда авторлар педагогтың білім алушылармен өзара әрекеттестікте эмпатиялық тәсілге бағдарлануды негізге алады. Осыған байланысты педагогтардың 5 типі қарастырылады.

1) Белсенді, оң кәсіби бағдарлы педагогтар. Бұл педагогтар білім алушылардың жай-күйіне эмоционалдық қатынас таныта алады. Олар білім алушылармен, әріптестерімен де ынтымақтастыққа негізделген қарым-қатынас құра алады.

2) Функционалды кәсіби бағдарлы педагог. Бұл педагогтарда оқушылардың жай-күйіне эмоционалдық қатынасы жеткіліксіз болады. Олар 
THEORETICAL FOUNDATIONS OF THE FUNCTIONING OF EDUCATION. WAYS TO IMPROVE THE EFFECTIVENESS OF EDUCATIONAL ACTIVITIES

нұсқау беру арқылы педагогикалық іс-әрекетті жүзеге асыратындықтан кәсіби тәжірибесінде ынтымақтастық болмайды, таңдамалы қарым-қатынас жасайды.

3) Бейтарап-енжар кәсіби бағдарлы педагог. Бұл педагогтар экспрессия арқылы эмоцияны тани алмағандықтан, вербалды қарым-қатынастың мазмұнына ерекше назар аударады. Олар іскерлік, ресми түрде қарым-қатынас жасауға бағытталып, білім алушылардың спонтанды тілдесуіне себепкер болады.

4) Ситуациялық кәсіби бағдарлы педагог. Бұл педагогтарда эмоционалдық жоғары болады, білім алушылардың жай-күйіне аяушылық сезіммен эмоционалдық қатынас білдіреді. Мұндай педагогтардың көңіл-күйі аумалытөкпелі боуына байланысты білім алушылармен өзара қатынасы да құбылмалы келеді.

5) Жасырынды теріс кәсіби бағдарлы педагог. Бұл педагогтар оқушылардың жай-күйіне эмоционалдық қатынас білдіре алмайды. Олар эмоцияның вербалды емес белгілерін тани алмайды.

Бұл типология педагогтардағы эмпатияның дамуын олардың білім алушыларға эмоционалдық қатынасы арқылы анықтап, қарастырады.

А.П. Панфилова [90, 32б.] педагогтарды «трансакциялық» және «трансформациялық» деп сипаттайды. «Трансакциялық» педагогтар ақпарат алмасу үдерісін ұйымдастырып, жүзеге асырады. Олар жұмысында сабақ беріп, міндетін ресми түрде атқарып кете беретін педагогтар болып табылады. Ал, «трансформациялық» педагогтар кәсіби іс-әрекетте маңызды бетбұрыстар мен өзгерістерді жүзеге асыруға қабілетті болады. Бұл педагогтар білім алушылардың дамуына, білім беру орнындағы мінез-құлық мәдениетінің бекуіне, білім беру технологияларын қолдануға байланысты оңды өзгерістер енгізеді. «Трансформациялық» педагогтар әр оқушының болашағына назар аударады. Бұл педагогтар білім берушілер мен әріптестер арасындағы ынтымақтастықты нығайтуға ұмтылады.

Олай болса, мұнда педагогтар кәсіби іс-әрекетті құзіреттілікпен жүзеге асыруға байланысты типтерге бөлінген. 
THEORETICAL FOUNDATIONS OF THE FUNCTIONING OF EDUCATION. WAYS TO

IMPROVE THE EFFECTIVENESS OF EDUCATIONAL ACTIVITIES

Көбінде педагогикалық іс-әрекеттің басты мақсаты білім алушының дамуы, тәрбиесі, оқу үдерісіндегі табыстылығы бойынша педагогтар типологиясы жіктеледі. Осыған байланысты, кейбір еңбектерде окушы тұлғасына бағыттылығы негізге алынып, педагог типтері ажыратылады.

В.Н. Сорока-Росинский $[91,456$.$] педагогикалық іс-әрекеттегі мұғалімнің$ бағыттылықтары мен олардың типтерін бөліп, сипаттауда олардың бағыттылығын негізге алады. Осыған байланысты мұғалімнің 2 түрлі бағыттылығы анықталған:

пәнге негізделу, сабақ мазмұнына шегенделу - «пәнге центризм»;

окушыларға бағытталу - «педоцентризм».

Осыдан педагогтардың сәйкесінше 2 типі ажыратылып, олардың ерекшеліктері сипатталады:

1) «логотроптар» - эмоционалдық реакциялары оқушының сабақтағы ісәрекеті мен жауабына байланысты жағымды-жағымсыз болып құбылмалы келеді; олар пән бойынша білімді ең басты көрсеткіш ретінде санайды;

2) «педотроптар» - оқушылардың жан-дүниесін терең түсінуге қабілетті; олармен бірге қуанып, бірге күйіне алатын; оларды аналық мейірімге бөлейтін; көмектесіп, қолдауға әрқашан дайын тұратын тұлға.

Сонымен қатар А.К. Мынбаева педагог тұлғасының бағыттылығына, ұстанатын позициясына байланысты 2 типке бөліп қарастырып,оларды бірбірімен салыстыра сипаттап, «педагог-қамқоршы» және «педагог-менеджер» деп ажыратады [92, 69-70 бб.]. Ол үшін педагогтың балаларға қатысты позициясы, ықпал етудегі стратегиялық тұрғысы, балаларға ықпал ету шараларын таңдауы, оқу материалын ұсыну тәсілін таңдауы, бағалау тұрғысы және қорытынды бағалау тәсілі педагог типтерін ажырату көрсеткіштері болып табылады. Автордың «педагог-қамқоршы» және «педагог-менеджер» позициялық типтеріне берген сипаттамасынан педагогтың тұлғалық қасиеттері айқын анықталады.

Жоғары мектеп оқытушысының типтік жіктемелерін И.Б. Назарова [93, 58б.] сауалнама жүргізу арқылы анықтаған. Бұл зерттеуде типология негізіне 
THEORETICAL FOUNDATIONS OF THE FUNCTIONING OF EDUCATION. WAYS TO IMPROVE THE EFFECTIVENESS OF EDUCATIONAL ACTIVITIES

жоғары мектеп оқытушыларының педагогикалық іс-әрекетке тұлғалық қатынасы алынады. Сонымен қатар оқытушылардың типтерге жіктелуінде олардың жалпы түрде еңбек етуге қатынасы, қосымша табыс табуға қатынасы басшылыққа алынған. Олтиптер былайша сипатталады:

«Титан» оқытушылар үшін «алдымен - ғылым, бірақ оқыту ісін қоймаймын, себебі кімге не оқу керектігін өзім таңдаймын» деген қатынаста болады. Олар ғылымда да, оқытуда да жеке жетістіктерімен де, еңбектерінің ақталуымен де барлық мүмкіндіктерге қолы жеткен адамдар. Материалдық тұрғыдан қамтамасыз етілген, әрқашан қызықты жұмыстары бар және үнемі қызықты ұсыныстар жасалып, қандай жұмысты істейтінін, қандайын істемейтінін таңдай алады. Олардың өздеріне қызықты іспен айналысуға жағдайлары бар. Жүктемелері көп емес, аптасына бір рет қана ЖОО-ға келеді. Өздерін қызықтырмайтын болғандықтан, олар жоғары мектепте болып жатқан жағдайлардан бейхабар. Олар үшін жоғары білім берудің өзгермегені жақсы. Олар ештеңені өзгерткілері келмейді әрі олар үшін бұл кеш. Олар өз өмірлерін қайта бастаса осы жолды таңдайтын болады.

1) «Академик» оқытушылар «мен оқытушы емеспін, мен оқытуға уақыт өткізгім келмейді, бірақ өзімнің тәжірибем мен білімімді жеткізуім керек» деген қатынаспен анықталады. Бұл тип өкілдері үнемі ғылыммен айналысып, бірақ ақырында жастарға өз білімін жеткізуді қажет деп санйды. Олар ғалым ретінде көпшіліктен мықты болғанмен, сабақ беруі ондай дәрежеге жетпейді.

2) «Өмір бойы» оқытушы типіндегі тұлғалар «оқыту - менің негізгі мамандығым, мен бурлак секілді өмір бойы осымен кеттім» деген қатынасты танытады. Олардың білім деңгейі жоғары, ғылыми дәрежесі, ғылыми атағы болады. Бұл топты өздерінің кәсіби тағдырын өзгерткісі келмейтін оқытушылар құрайды.

3) Көптеген жұмысқа қамтылған оқытушылар типі «мен барлық жұмысты істей аламын, себебі отбасының негізгі асыраушысымен, маған ақша табу керек және мансабымды өсіру керек» деген қатынаспен сипатталады. Бұл топтағы оқытушылар оқытуда да, ғылымда да көп жүктеме алады. 
THEORETICAL FOUNDATIONS OF THE FUNCTIONING OF EDUCATION. WAYS TO

IMPROVE THE EFFECTIVENESS OF EDUCATIONAL ACTIVITIES

4) «Тірегі мықты» оқытушылар үшін «ақша мені қызықтырмайды, бірақ маған университеттің оқытушысы ретінде танылған тартымды болады» деген қатынас алға қойылады. Олар өмір бойы оқытумен айналысуға дайын болады. Жұмысын, білім алушыларды жақсы көреді. Бұл оқушылар жақсы білім алғандар, оқыту және зерттеу жұмыстары бойынша тәжірибелері болады.

5) «Аяқтап қалған» оқытушылар «енді бірнәрсені өзгерту кеш, пенсияға қосымша болсын деп көп емес жүктемем бар, құрмет пен қарым-қатынас бар» деген қатынаспен сипатталады. Олардың тәжірибелері көп, сондықтан сабаққа дайындалмай келеді. Және өздерінің ғылыми жетістіктері, ғылыми дәрежелері мен ғылыми атақтарына үстеме алып, сабақ бергенді ұнататын оқытушы типтері.

6) «Практик» оқытушы типтері шенеунік, саясаткер, кәсіпкер тұлға ретінде «мен нақты экономикалық жағдайды білемін, заманауи бизнес әлемінен тәжірибе бере аламын, мені шақырған соң келгенмін» деген қатынас бойынша топ құрайды. Бұл оқытушылар сабақ беру мен ғылыми жетістіктерге байланысты регалийлер алу үшін жанталаспайды.

7) «Статус адамдарының» типі бойынша жіктелетін оқытушылар «менің ата-тегімнің тұсында директор деп қана жазылмай, экономика ғылымдарының докторы деп тұрғанын қалаймын» деген қатынаспен ерекшеленеді. Олардың бизнесте аса табысты болса да, ғылым мен оқытуда жетістіктері болғанын қалайды. Олар үшін ғылыми атақ, ғылыми дәреже алу маңызды. Сол үшін ақша төлеп, біреулермен бірігіп монографиялар шығарып жүреді. Сабақ беруге уақыты жоқ болғандықтан үнемі өзін алмастыратын әріптестер іздеуде болады.

8) «Бизнес-леди» оқытушы типі университетте өз бизнесі мен оқытуды сабақтастыру ниетімен, жоғары мектепте білім берумен ермек үшін айналысатын топтағы тұлғалар. Олар жоғары мектепте тұрақталып жұмыс істей алмайды.

9) «Ғылыми-педагогикалық тандем» типіндегі оқытушылар «екеуіміз де университеттеміз, ғылыми жұмыспен айналысамыз» деген қатынасты көрсетеді. Олар үшін ЖОО-дағы қызмет негізгі болып саналады. 
THEORETICAL FOUNDATIONS OF THE FUNCTIONING OF EDUCATION. WAYS TO

IMPROVE THE EFFECTIVENESS OF EDUCATIONAL ACTIVITIES

Бұл жоғары мектеп оқытушыларының типолдогиясы қазіргі қоғамдық жағдайдың ерекшеліктерін ескереді. Сондықтан мұнда сипатталған оқытушы типтерін әлдеқайда заманауи және реалды деп санаймыз.

А.В. Юревич [94, 67б.] жоғары мектеп оқытушыларын типологиялық жіктемесін тұлғалық негізде құрып, студенттерге қатынасы мен өз пәні бойынша білім берудегі қаталдығы бойынша оқытушылардың 6 типін анықтап, келесідей сипаттаған:

- Өзін-өзі көрсетіп қалуға ұмтылатын оқытушылар студенттер үшін аса қолайсыз болады. Олар студенттерді қорқыту арқылы немесе бағаны жоғарылатып қою арқылы өзін құрметтетуге тырысады.

- Педант оқытушы да студенттерге қолайсыз болады. Олар қырсықтықпен, догматизм мен таяздықпен ерекшеленеді. Емтихан кезінде дәлме-дәл жауап күтіп, білім алушылар тарапынан шығармашылыққа, тапқырлыққа жол бермейді.

- Немқұрайлық оқытушы типі субъективті маңызды жұмыстарды алға қояды. Студенттердің аты-жөні, кесте бойынша сабақ, объективті білім бағалау оның назарын аудармайды. Есесіне өзі шетелге іс-сапар, өзінің кітаптарын шығару, грант алу сияқты мәселелер маңызды болып табылады.

- Жалқау оқытушы типі пән бойынша дайындалмайтын, салақ, ұқыпсыз жүретін, жаман әдеттермен ерекшеленетін тұлға болып табылады. Бірақ ондай оқытушы мейірімді, бағаға жомарт келеді.

- Ағайыншылықпен сипатталатын оқытушы типі студенттерге барынша жақын болуға тырысатын, оларды жаман әдеттерге тартатын, жастар сленгісін қайталайтын тұлға. Бұл типтің өкілдері тек «жақсы» және «өте жақсы» деген бағаны ғана білетін секілді. Бірақ бағалауда олар әрқашан әділетті болмай, өте жақсы жауапты төмендетуі де мүмкін.

- Студенттердің ерекше ұнататындары романтик оқытушылар типінің өкілдері болады. Ол үшін ең бастысы тәртіп пен баға емес, студенттердің шығармашылығы мен ойлауы болып табылады. Оның лекциялары мен семинар сабақтары диалог арқылы жүргізіледі. Бұл типтің өкілдері өз мамандығына, 
THEORETICAL FOUNDATIONS OF THE FUNCTIONING OF EDUCATION. WAYS TO

IMPROVE THE EFFECTIVENESS OF EDUCATIONAL ACTIVITIES

ғылымға ерекше қатынасы байқалып, онымен студенттерді шабыттандырып отырады.

Бұл типология жоғары мектептегі оқытушының іс-әрекетінде, қарымқатынасында, өзіне және басқаларға қатынасында аса күрделі психологиялық, педагогикалық және әлеуметтік мәселе бар екенін көрсетеді.

Қазіргі кездегі жоғары мектеп оқытушыларының басқа адамдар секілді әр түрлі қасиеттермен ерекшеленетіні Л.Д. Столяренконың [95, 119б.] типологиясында көрінеді. Автор оқытушылардың студенттермен қарым-қатынас кезіндегі мінез-құлқын жүйелеген. Осыған байланысты жоғары мектеп оқытушыларының типологиялық жіктемесінде мінез-құлықтың 8 моделін қамтиды. Л.Д. Столяренконың анықтаған оқытушы модельдері төменде келтірілген.

«Монблан» студенттерге жақындамайтын, өз білгеніне масаттанып, студенттермен тұлғааралық өзара қатынастарды қажет етпейтін диктатор оқытушы типі болып табылады.

«Қытай қабырғасы» дейтін типтерге студенттермен қарым-қатынасқа тосқауыл қоятын, сабақта диологты құрмайтын, студенттерді менсінбейтін оқытушылар жатады.

«Локатор» типіндегі оқытушылардың өкілі студенттерді таңдап, өзара қатынас орнататын, оларды алалап, контакт жасайтын тұлғалар.

«Құр» немесе «саңырау құр» өз әлемінде, өзімен өзі жүретін; басқаларға құлақ аспайтын, монологты сөйлейтін оқытушының типін сипаттайды.

«Гамлет» типі өзінің қалай қабылдайтынына, іс-әрекетінің дұрыстығына, студенттердің өзіне деген қатынасына ерекше көңіл аударатын оқытушылар тобын құрайды.

«Робот» типі студенттермен қарым-қатынасы оку бағдарламасының аясынан шықпайтын, олардың психологиялық ерекшеліктерін есепке алмайтын оқытушыларға сәйкес келеді.

«Мен-өзім» типі бойынша оқыту-тәрбиелеу үдерісінде әрқашан өзін ғана басшы және инициатор ретіндегі жалғыз тұлға көретін оқытушы анықталады. 
THEORETICAL FOUNDATIONS OF THE FUNCTIONING OF EDUCATION. WAYS TO

IMPROVE THE EFFECTIVENESS OF EDUCATIONAL ACTIVITIES

«Одақ» типіне қамтылатын оқытушылар студенттермен диалог арқылы қарым-қатынас жасайды, достық негізде жанашырлық көрсете алады.

Қазіргі кезде педагогикалық, психологиялық зерттеулерде педагогтың кәсіби іс-әрекетінің жалпыланған, ықпалдасқан сипаттамалары типологияның бір ғана негізі ретінде қаралмайды. Ғылымдағы педагогтардың типологиялық жіктемелерінде көбінесе жеке-дара кәсіби қабілеттер болатын тұлғалық құрылымдар басты параметр болып табылады. Сонымен қатар, ғылыми зерттеулерде педагогтар типологиясына маманның кәсіби іс-әрекет барысында қарым-қатынас жасауға қабілеті немесе өз пәні арқылы білім алушыларды қызықтыра алуы немесе педагогтардың психологиялық жекедара қасиеттерінің ерекше даму деңгейлері сияқты тұлғалық интеграцияланған құрылымдар қарастырылады.

Жоғары мектеп оқытушысының тұлғалық даму ерекшеліктеріне байланысты олардың типологиялық жіктелуі педагогикалық-психологиялық мәселе ретінде жан жақты зерттеуді қажет етеді. 